Original Contribution

\title{
POSTHARVEST LIFE OF CUT GERBERA FLOWERS AS AFFECTED BY SALICYLIC ACID AND CITRIC ACID
}

\author{
H. Heidarnezhadian, B. Eghbali, M. Kazemi* \\ Agricultural Bank, Ilam Branches, Ilam, Iran
}

\begin{abstract}
Effect of salicylic acid (SA) combined with citric acid (CA) on gerbera (Gerbera jamesonii) cut flowers was studied. The study was conducted in a factorial arrangement, carried out in a complete randomized design. The factors were SA $(0.5,1.5$ and $3 \mathrm{mM})$ and $\mathrm{CA}(1.5$ and $3 \mathrm{mM})$. The effects of treatments on the total chlorophyll content, anthocyanin leakage and malondialdehyde content of cut flowers of gerbera were investigated. The results showed that the vase solution containing $1.5 \mathrm{mM} \mathrm{SA}$ significantly increased vase life compared to the control. In addition, the malondialdehyde accumulation reduced in the same solution while membrane stability was improved. Results suggest that SA increases vase life by affecting many of the age-related changes associated with Gerbera petal senescence.
\end{abstract}

Key words: Cut flower, Gerbera, Salicylic acid, Citric acid, Vase life

\section{INTRODUCTION}

Flowers are extremely perishable; maintaining their physiological functions vary actively even after harvest and the beginning of their senescence very often depends on ethylene. Short postharvest vase life is one of the most important problems on the cut flowers. In carnations, senescence of the petals is associated with a climacteric-like increase in ethylene production during the final stages. Ethylene production causes a sharp increase in production of oxygen free radicals which is responsible for stress dependent peroxidation of membrane lipids (1). Salicylic acid (SA) is a well known phenol that can prevent ACCoxidase activity that is the direct precursor of ethylene and decrease ROS with increase enzyme antioxidant activity. SA is considered as a hormone-like substance, which plays an important role in regulating a number of physiological processes and provide protection against biotic and abiotic stresses in plant. Salicylic acid is the most readily accessible plant growth regulators which are effective in other forms of acetyl salicylic acid and methyl salicylate in plant as well (2). Salicylic acid could induce the alternative oxidase enzyme activity in mitochondria which is involved in

\footnotetext{
*Correspondence to: Mohsen Kazemi,

Agricultural Bank, Ilam Branches, Ilam, Iran,

E-mail: kazemimohsen85@gmail.com
}

stress alleviation mechanism and enhancing or reduction in specific secondary metabolites of plants is reported (3). Mei-hua et al., (4) showed that SA can extending the vase life of cut flowers with decrease ROS and ethylene. Citric acid seems to act by reducing the $\mathrm{pH}$ of water and, consequently, the proliferation of bacterial, which block the xylem vessels in the cut region and interfere with the normal flux of water through the stem (5). Therefore, in this study, the preservative effects of SA and CA and their interaction on the vase-life of cut gerbera flowers were studied.

\section{MATERIALS AND METHODS}

This study was the effect of SA and CA treatments on vase life of gerbera cut flowers, in a factorial test with complete randomized design with 4 replications. Cut flower stems of gerbera were placed in solution containing SA $0.5,1.5$ and $3 \mathrm{mM}$ and CA 1.5 and 3 after cutting. Four cut flowers were placed in a 300 $\mathrm{mL}$ flask with $250 \mathrm{~mL}$ of solution. Distilled water was used for the controls and placed in chambers at $19^{\circ} \mathrm{C}$. The relative humidity was about $75 \%$ while $14 \mathrm{~h}$ photoperiod was maintained using fluorescent lamps with a light intensity of $15 \mu \mathrm{mol} \mathrm{m} \mathrm{m}^{2}$ at the top of the corolla. Vase life was determined as the number of days to wilting of flowers. Total chlorophyll $(\mathrm{a}+\mathrm{b})$ content was measured by chlorophyll meter which is presented by SPAD 
value. Anthocyanin leakage was measured based on the method of Poovaiah (6). MDA content was measured based on the method of Heath and Packer (7). Data were statistically analyzed using SPSS software. The mean separation was conducted by Duncan's analysis in the same software $(p \leq 0.05)$.

\section{RESULTS AND DISCUSSION}

Holding gerbera cut flowers in vase solutions containing $1.5 \mathrm{mM}$ SA significantly increased their vase life and delayed flower senescence compared to flowers either held in 0.5 and 3 $\mathrm{mM}$ SA or distilled water $(\mathrm{p} \leq 0.05)$ (Table 1). In our experiment adding $\mathrm{CA}(3 \mathrm{mM})$ to vase solutions containing SA could increase the vase life of cut flowers compared to control ( $p$ $\leq 0.05$ ) (Table 1). The results indicate that 1.5 $\mathrm{mM}$ SA caused significant decrease anthocyanin leakage and MDA content compared to control $(\mathrm{p} \leq 0.05)$ (Table 1). MDA content was reduced by SA and was significantly lower in solution preservative containing SA compared to the control and CA
HEIDARNEZHADIAN H., et al. ( $\mathrm{p} \leq 0.05$ ) (Table 1). Result showed that 1.5 $\mathrm{mM} \mathrm{SA}+1.5 \mathrm{mM}$ CA leaded to a considerable delay in degradation of chlorophyll compared to other treatments $(\mathrm{p} \leq 0.05)$ (Table 1$)$. SA is one of the endogenous signals which play an important role in plant defense. SA required for basal resistance against pathogens as well as for the inducible defense mechanism, systemic acquired resistance (SAR), which confers resistance against a broad-spectrum of pathogens (8). Also, SA inhibited the ethylene biosynthesis and delayed senescence progress in plant tissues (9). These results are in agreement with those of $(10,11)$ who found that adding SA, MA and GLU in vase water increased chlorophyll content cut flowers. similarity, Canakci (12) reported that treatment with salicylic acid significantly extends the vase life with increases chlorophyll content. Yuping (13) reported that treatment with salicylic acid significantly extends the vase life with increases the enzyme antioxidant activity and decreased ROS production.

Table 1. Effects of salicylic acid and citric acid in preservative solution on chlorophyll content, Vase life, Membrane stability, MDA in gerbera cut flowers

\begin{tabular}{ccccc}
\hline Treatments & $\begin{array}{c}\text { Vase life } \\
\text { (day) }\end{array}$ & $\begin{array}{c}\text { Total } \\
\text { chlorophyll } \\
\text { (SPAD reading) }\end{array}$ & $\begin{array}{c}\text { Antocyanin leakage } \\
\text { (absorption at 525 nm) }\end{array}$ & $\begin{array}{c}\text { MDA } \\
(\mu \mathrm{mol} / \mathrm{mg} \\
\text { protein })\end{array}$ \\
\hline Control & 6.54 & 2.04 & 110.21 & 121.07 \\
\hline $0.5 \mathrm{SA} \mathrm{mM}$ & 7.32 & 2.98 & 104.36 & 67.14 \\
\hline $1.5 \mathrm{SA} \mathrm{mM}$ & 12.41 & 3.89 & 54.65 & 52.25 \\
\hline $3 \mathrm{SA} \mathrm{mM}$ & 9.65 & 3.01 & 75.65 & 75.41 \\
\hline $1.5 \mathrm{CA} \mathrm{mM}$ & 7.00 & 3.05 & 90.65 & 79.58 \\
\hline $3 \mathrm{CA} \mathrm{mM}$ & 7.65 & 3.14 & 89.65 & 80.65 \\
\hline $1.5 \mathrm{SA} \mathrm{mM}+1.5 \mathrm{CA} \mathrm{mM}$ & 10.52 & 4.14 & 60.54 & 76.54 \\
\hline $1.5 \mathrm{SA} \mathrm{mM} \mathrm{+3} \mathrm{CA} \mathrm{mM}$ & 10.74 & 3.14 & 74.65 & 98.54 \\
\hline
\end{tabular}

\section{CONCLUSION}

The effect of SA on senescence and vase life extension of cut flowers was reported earlier which is confirmed here was anticipated. This study shows that salicylic acid treatment did show significant effect on quality parameters and gerbera flower longevity. Salicylic acid proved more effective in delaying petal senescence and/or flower wilting.

\section{REFERENCES}

1. Reezi, S., Babalar, M., and Kalantari, S., Silicon alleviates salt stress, decreases MDA content and affects petal color of salt stressed cut rose (Rosa xhybrida L.) 'Hot
Lady'. African J. Biotechnol, Vol. 8, pp. 1502-1508, 2009.

2. Raskin, I, Role of salicylic acid in plants. Annual Review of Plant Biology, Vol. 43(1), pp. 439-63, 1992.

3. D'Onofrio, C., Cox, A., Davies, C., and Boss, P.K., Induction of secondary metabolism in grape cell cultures by jasmonates. Functional Plant Biology, Vol. 36(4), pp. 323-38,2009.

4. Mei-hua, F., Jian-xin, W., SHI, L., SHI, G., and Fan, L., Salicylic Acid and 6-BA Effects in Shelf-life Improvement of Gerbera jamesonii Cut Flowers. 2008.

5. Nowak, J., and Rudniki, R.M., Postharvest handling and storage of cut flowers, florist 
greens and potted plants. Timber Press, Portland. 1990.

6. Poovaiah, B.W., Increased levels of calcium in nutrient solution improves the postharvest life of potted roses. J. Amer. Soc. Hort. Sci, Vol.104, pp. 164-166, 1979.

7. Heath, R.L., and Packer, L., Photo peroxidation in isolated chloroplast. Kinetics and stochiometry of fatty acid peroxidation. Arch. Biochem. Biophys, Vol. 125, pp. 189-198, 1978.

8. Chaturvedi, R., and Shah, J., Salicylic acid in plant disease resistance. In Hayat $S$. Ahmad A (eds.) Salicylic Acid - A Plant Hormone, Springer, Dordrecht, The Netherlands, pp. 335-370, 2007.

9. Leslie, C., and Romani, R., Salicylic acid: a new inhibitor of ethylene biosynthesis. Plant Cell Rep, Vol. 5, pp. 144-146, 1986.

10.Kazemi, M, Aran, M., and Zamani, S., Interaction between glutamin and different chemicals on extending the vase life of Cut Flowers of 'Prato' Lily. American Jjournal of Plant Physiology, Vol.6(2), pp.120-125, $2011 \mathrm{a}$.

11.Kazemi, M., Aran, M., and Zamani, S., Extending the Vase Life of Lisianthus (Eustoma grandiflorum Mariachii. cv. blue) with Different Preservatives. American J of Plant Physiology, Vol. 6(3), pp.167-175, $2011 \mathrm{~b}$.

12.Canakci, S., Effects of salicylic acid on fresh weight change, chlorophyll and protein amounts of radish (Raphanus sativus L.) seedlings. J. Biol. Sci, Vol. 8, pp. 431-435, 2008.

13. Yuping, Z., Effects of salicylic acid on fresh keeping of cut gerbera jamesonii flower. Anhui Agricultural 291 Science Bulletin.

http://en.cnki.com.cn/Article_en/CJFDTOT AL-AHNB200913063.htm. 2009. 